\title{
CURRICULUM MANAGEMENT QUALIFICATION IN EDUCATION AND THE SITUATION IN ROMANIA
}

\author{
Ioana Magdaș
}

\begin{abstract}
In this study, we analyzed the Curriculum Management (CM) qualification in education and the competences this qualification requires. Moreover, we analyzed the current situation and the future needs of CM specialists within the Romanian educational system. The research used a combination of qualitative and quantitative methods as follows: a content analysis of official documents, the analysis of existing CM programs in Romania, and a triangulated methodology. The novelty of this research consists of the identification, centralization, and classification of the $\mathrm{CM}$ competencies in six categories. Four out of five participants in the research considered that there is a high need for curriculum managers in Romania, given that currently, only $15.5 \%$ of teachers have such competencies. As a future perspective of the Romanian educational system, it would be necessary that over a third by 2023 , respectively almost a half by 2028 of teachers, to be trained and have competences-in the CM field. The providers of training programs and universities in Romania are recommended to introduce new CM programs whose curricula and subjects to be corelated with the competences identified.
\end{abstract}

Keywords: Curriculum management qualification, competences, education, Romania

\section{Introduction}

To adapt the education systems to the rapid changes of the society and to the information and communication technology development, it is necessary to update the educational policies and to implement extensive reforms. Between 2008 and 2014, the Organization for Economic Co-operation and Development [OECD] countries adopted no fewer than 450 education reforms (Viennet and Pont, 2017). Bocoș and Chiș (2013) emphasize that any educational reform occurs mainly in the field of the curriculum while its (re)construction is being kept in the background. The concept of Curriculum Management (CM) occurs by interfering with two concepts that are usually treated separately, i.e., curriculum and management, and it is considered subordinated to educational management. While "the educational management has to be centrally concerned with the purpose or aims of education" (Bush, 2008 , 2), the purpose of CM is to make relevant curricular decisions and achieve curricular goals (Bocoș and Chiș, 2013). We can consider that a curriculum manager is a person responsible for CM. Although the specialized literature pays great attention to educational management, the subdomain of $\mathrm{CM}$ has not been systematically studied. Thereby, it is necessary to analyse the importance of CM in education.

As Secretary-General of the European Schools, Kivinen shows that "school providers, school heads, teachers, parents and policy-makers all over Europe are interested how we can reform the school system, build up the compulsory and a differentiated curriculum to provide students with the right set of competencies for future" (Leaton Gray, Scott and Mehisto, 2018, VIII). Schleicher (2012, 33) shows that "in many countries, extensive curriculum, training, and assessment reforms have been undertaken with the intention of providing a better education needed to meet the demands of life and work in the 21st century". The European Centre for the Development of Vocational Training [Cedefop] $(2012,1)$ mentions that "curricula change to reflect shifting trends in education, training, and labour market". 
According to the European Trade Union Committee for Education (ETUCE, 2012, 7) "as education systems are seeking to adapt to the needs of contemporary society, the expectations of schools and school leaders have changed profoundly". One of the tasks-of-school leaders is the pedagogical one which "refers to those tasks, which relate to teaching and learning, including curricular design, supervision and mentoring" (ETUCE, 2012, 35). According to OECD (2008, 46) "much of the research literature on effective leadership has emphasized curricular decision making as a key dimension of leadership for improved student learning".

The educational reforms aim at a decentralization of the curriculum at the school level, and it can reach a massive decentralization of up to $90 \%$ at the level of courses (eg Japan and New Zealand) and / or content (eg Japan, Poland and Korea) (OECD, 2008). In some other countries such as England (Bush 2016) and Romania (Kitchen, Fordham, Henderson, Looney, and Maghnouj, 2017) the curriculum has remained centralised, its implementation is monitored by certain institutions, and its implementation is made by school principals and teachers. According to $\operatorname{OECD}(2008,24)$ "school leaders are increasingly expected to align local curricula with centrally mandated standards during their planning processes". Mestry $(2017 \mathrm{a}, 8)$ established that "principals can make a significant contribution to schools' achieving educational goals and improving learner performance, if they are adequately pre-pared for their leadership role". The roles of school principals and the areas in which they should perform are analyzed in various studies. Marsch $(2004,94)$ lists the functions and areas where principals must show their leadership. Eddy-Spicer, Bubb, Earley and James (2019) identified ten characteristics of a performance leadership.

Bush (2016, 10-11) shows that "in many countries, school leaders begin their professional careers as teachers and progress to headship via a range of leadership tasks and roles often described as <middle leadership>". According to the European Commission (2012) "school headship and leadership should be a career path that is chosen and prepared for, rather than a forced or accidental assignment". In the same report, it is specified that in some European Union (EU) States, there is an average of only 1.25 candidates who apply per position, and some causes for that situation are identified, namely: the headship involves predominantly administrative or managerial duties rather than higher-order leadership or pedagogical leadership tasks; the lack of external support within the educational leadership; the salaries are not attractively and they have often besides administrative tasks also a heavy teaching load (European Commission, 2012).

In the literature, we meet various opinions on the principals' skills regarding the curriculum. In older studies, the CM is considered the main attribution of the principals which is allocated the most time (Morphet, John and Reller, 1982, 300; Donmoyer and Wagstaff, 1990, 20). Boyd (1996, 65) states that there has recently been a demand for principals to be instructional leaders as well as curriculum managers. Portin, Shen and Williams (1998) consider that curriculum supervising and improving the instructional programs of the school are-a part of the leadership. Botha $(2004,240)$ suggests that "principals' tasks should also be less administrative and more focus on being educational leaders". In studies conducted more recently, researchers found that CM duties of principals are reduced (Goslin, 2009; European Commission, 2012). In addition, "many school principals repudiated claims that their primary function was to manage teaching and learning" (Mestry, 2017b, 257). European Commission (2012) shows that "school leaders spend more than $40 \%$ on average of their time on management and administrative activities rather than, for example, developing curriculum and pedagogical activities, teaching, or communicating with parents and students". According to $\operatorname{OECD}(2008,46)$ "much of the research literature on effective leadership has emphasized curricular decision making as a key dimension of leadership for improved student learning".

The European Commission $(2018,14)$ shows that "however schools are organized, and whatever curricula are taught, pupils are ultimately dependent for their competence development on the expertise, energy, inspiration and imagination of the adults to whom they are entrusted". Due to the curriculum complexity, teachers must have curricular abilities and able to play many roles as: curriculum manager, curriculum designer, curriculum applicant, curriculum developer; curriculum facilitator, curriculum monitor, and curriculum evaluator (Bocoș and Chiș, 2013). In Romania, it has been found that teachers often face difficulties in teaching the new curriculum (Kitchen, Fordham, Henderson, Looney and Maghnouj, 2017). 
Therefore, the educational reform process is mainly carried out by principals and teachers and the role of teachers in a good instruction of students is essential and depends to a large extent on the level of CM competences they have.

Based on these considerations, we conducted a study analyzing the Curriculum Management (CM) qualification in education, the competences this qualification requires, the current situation and the future needs of $\mathrm{CM}$ specialists within the Romanian educational system. In carrying this out, we started from the following questions:

1. What are the occupations in the educational field that require CM tasks?

2. What qualifications in the CM field offer the Romanian educational system?

3. What occupations can be practiced by the CM specialists in the Romanian educational system?

4. What are the curriculum manager competencies?

5. How necessary is the CM qualification within the Romanian educational system?

6. What is the current situation and the need in the future (until 2023, respectively 2028) of qualified teachers in CM?

\section{Method}

\subsection{Research design}

The research included a combination of qualitative and quantitative methods as follow: a documentary analysis, after that during November - December 2018 we applied a triangulated methodology consisting of focus-group, semi-structured interviews and online questionnaires. The three instruments of the triangulated methodology offered us complementary perspectives. the focus groups and questionnaire were attended by people with leadership positions in the Romanian education system, while for the individual interviews we selected teachers to identify whether their opinion converges with that of leaders. The methods were gradually applied, all methods being treated under equal conditions, which respects the requirements of research based on the triangulated methodology (Flick, 2014). The social context in which the discourse took place during focus groups and individual interviews is qualitatively different. In the focus group, "members comment on each other's point of view, often challenging each other's motives and actions in a pointed fashion" (Kidd and Parshall, $2000,294)$. In contrast, during the individual interviews, the interviewee addressed his speech to the interviewer who expressed empathy (Kvale, 2008).

\subsection{Data Collection and Analysis}

The first stage of the research consists of a documentary analysis regarding the CM qualification (official sites, laws and methodologies) based on which, we formulated the standardized open questions for the focus-group, respectively for the individual interviews and we also developed the questionnaire. The questions were related to the research questions listed above and were validated by two academic experts.

The second stage of the research consists in the application of the triangulated methodology methods. Both the focus group and individual interviews were conducted face to face. The focus group lasted about two hours, while the individual interviews lasted about an hour each. The collection of participants' responses to the focus group and individual interviews was done by recording the conversation without editing. Later a researcher identified the main ideas conveyed to the focus group, and another researcher centralized the answers from the interviews and coded them for validity. The questionnaire was created using the Google Forms application from Google Drive. It was addressed to leadership persons within the Romanian educational system. In the first part of the questionnaire, we collected data on the professional experience of the respondents. The second part included nine questions regarding the necessity of the MC qualification, the competences of a curriculum manager, the number of qualified teachers in the MC field, as well as a future prediction for qualified MC teachers in Romania. Four of the items were with the choice on a 5-points Likert scale, the rest of 
them being open-ended items. For the answers to the closed items, averages were calculated. Moreover, the answers obtained by the three triangulated instruments were compared to identify if there is a convergence of the answers.

The third stage of the research consisted in determining whether the number of master programs in the field of CM in Romania covers the need for qualified personnel in this field, and if not, which is the prediction regarding the need for qualified personnel in the CM for the following years (2023 and 2028 respectively).

In table 1. The information about data collection and analysis used in our research as well as the results correlated to each research question and research tool were summarized.

Table 1. Information about data collection and analysis

\begin{tabular}{|c|c|c|c|c|c|c|}
\hline \multirow{2}{*}{$\begin{array}{l}\text { Stage } \\
\text { no. }\end{array}$} & \multirow{2}{*}{$\begin{array}{l}\text { Research } \\
\text { question } \\
\text { no. }\end{array}$} & \multicolumn{4}{|c|}{ Data collection tools } & \multirow[t]{2}{*}{ Results } \\
\hline & &  & 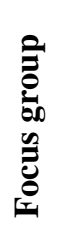 & 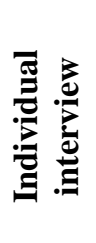 &  & \\
\hline \multirow[t]{2}{*}{ I. } & 1. & $\checkmark$ & & & & $\begin{array}{l}\text { List of occupations in the educational field that require } \\
\text { tasks of CM. }\end{array}$ \\
\hline & 2. & $\checkmark$ & & & & $\begin{array}{l}\text { List of qualifications in the field of CM within the } \\
\text { Romanian educational system. }\end{array}$ \\
\hline \multirow[t]{5}{*}{ II. } & 3. & $\checkmark$ & $\bar{\checkmark}$ & $\checkmark$ & & $\begin{array}{c}\text { List of existing occupations and new occupations that } \\
\text { should be introduced to be practiced by the CM } \\
\text { specialists on the Romanian labour market. }\end{array}$ \\
\hline & & $\checkmark$ & $\checkmark$ & $\checkmark$ & & $\begin{array}{l}\text { The legislative and institutional aspects that } \\
\text { need clarification and revisions to align the Romanian } \\
\text { educational system with the international one. }\end{array}$ \\
\hline & 4. & $\checkmark$ & $\checkmark$ & $\checkmark$ & $\checkmark$ & $\begin{array}{l}\text { The list of curriculum manager competencies and their } \\
\text { ranking according to importance. }\end{array}$ \\
\hline & & $\checkmark$ & $\checkmark$ & $\checkmark$ & $\checkmark$ & $\begin{array}{l}\text { The classification of curriculum manager competencies } \\
\text { in categories }\end{array}$ \\
\hline & 5. & & $\checkmark$ & $\checkmark$ & $\checkmark$ & $\begin{array}{l}\text { The level of necessity expressed by a value } \\
\text { between } 1 \text { to } 5 \text {, and a list of reasons justifying this } \\
\text { score. }\end{array}$ \\
\hline \multirow[t]{3}{*}{ III. } & 6. & $\checkmark$ & $\checkmark$ & & $\checkmark$ & $\begin{array}{c}\text { The CM competence level of teachers in Romania } \\
\text { expressed by an average percentage of qualified } \\
\text { teachers in school institutions. }\end{array}$ \\
\hline & & $\checkmark$ & $\checkmark$ & & $\checkmark$ & $\begin{array}{c}\text { Number of teachers at regional and national level that } \\
\text { need to be qualified in the CM domain by } 2023, \\
\text { respectively } 2028 .\end{array}$ \\
\hline & & $\checkmark$ & $\checkmark$ & & $\checkmark$ & $\begin{array}{l}\text { Establishing if the number of CM programs in } \\
\text { Romania cover the necessity of training specialists in } \\
\text { this field. }\end{array}$ \\
\hline
\end{tabular}

\subsection{Participants}

The focus group method was applied to a group of 10 persons with leadership positions within the Romanian educational system which were selected to cover all types of educational institutions, Teacher Training Centres and School Inspectorates (Table 2). All participants in the focus group have at least 12 years of leadership experience and a Master's degree. 
Table 2. Information about focus-group participants

\begin{tabular}{|c|c|c|c|c|c|c|}
\hline $\begin{array}{l}\text { Crt. } \\
\text { No. }\end{array}$ & Position & $\begin{array}{l}\text { Institution type/ } \\
\text { Classes type }\end{array}$ & $\begin{array}{l}\text { Institution } \\
\text { location }\end{array}$ & Gender & $\begin{array}{l}\text { Highest } \\
\text { studies }\end{array}$ & $\begin{array}{c}\text { Seniority in } \\
\text { leadership } \\
\text { position }\end{array}$ \\
\hline 1. & Principal & $\begin{array}{l}\text { Theoretical High school/ } \\
\text { Primary, Middle, High- } \\
\text { School classes }\end{array}$ & Urban & Male & $\mathrm{Ph} \mathrm{D}$ & 24 years \\
\hline 2. & Principal & $\begin{array}{l}\text { Theoretical High school } \\
\text { for minorities/ Primary, } \\
\text { Middle, High-School } \\
\text { classes }\end{array}$ & Urban & Female & $\begin{array}{l}\text { Master's } \\
\text { degree }\end{array}$ & 22 years \\
\hline 3. & Principal & $\begin{array}{l}\text { Technological High- } \\
\text { School/ } \\
\text { High-School classes }\end{array}$ & Urban & Female & $\begin{array}{l}\text { Master's } \\
\text { degree }\end{array}$ & 26 years \\
\hline 4. & Principal & $\begin{array}{l}\text { Technological High- } \\
\text { School/ } \\
\text { High-School classes }\end{array}$ & Rural & Male & $\begin{array}{l}\text { Master's } \\
\text { degree }\end{array}$ & 20 years \\
\hline 5. & Principal & $\begin{array}{c}\text { Vocational High school/ } \\
\text { Primary, Middle, High- } \\
\text { School classes }\end{array}$ & Urban & Male & $\begin{array}{l}\text { Master's } \\
\text { degree }\end{array}$ & 12 years \\
\hline 6. & Principal & $\begin{array}{c}\text { Secondary school for } \\
\text { inclusive education/ } \\
\text { Primary, Middle School } \\
\text { classes }\end{array}$ & Urban & Female & $\begin{array}{l}\text { Master's } \\
\text { degree }\end{array}$ & 14 years \\
\hline 7. & Principal & Kindergarden & Urban & Female & $\begin{array}{l}\text { Master's } \\
\text { degree }\end{array}$ & 16 years \\
\hline 8. & Principal & $\begin{array}{c}\text { Secondary school/ } \\
\text { Kindergarden, Middle } \\
\text { School classes }\end{array}$ & Rural & Female & $\begin{array}{l}\text { Master's } \\
\text { degree }\end{array}$ & 22 years \\
\hline 9. & $\begin{array}{l}\text { School } \\
\text { inspector }\end{array}$ & Preschool education & $\begin{array}{l}\text { Urban and } \\
\text { Rural area }\end{array}$ & Female & $\begin{array}{l}\text { Master's } \\
\text { degree }\end{array}$ & 18 years \\
\hline 10. & Director & $\begin{array}{l}\text { Teacher training centre/ } \\
\text { Teacher programs }\end{array}$ & Urban & Male & $\begin{array}{l}\text { Master's } \\
\text { degree }\end{array}$ & 14 years \\
\hline
\end{tabular}

For the individual interviews we randomly selected eighteen educational institutions to ensure the representativeness of all types of institutions (Table 3.). We conducted individual interviews with Curriculum Commission responsible people from each institution. All participants have a teaching experience of at least 12 years, have the highest didactic degree, graduated a master's program in Education Sciences and attended training courses in Educational Management.

Table 3. Sample distribution of individual interviews

\begin{tabular}{cccc}
\hline $\begin{array}{c}\text { Classes to which respondents } \\
\text { teach }\end{array}$ & Urban & Rural $^{*}$ & Total \\
\hline Theoretical High School & 2 & - & 2 \\
Technological High School & 1 & 1 & 3 \\
Vocational High School & 2 & - & 2 \\
Middle School & 2 & 2 & 4 \\
Primary School & 2 & 2 & 4 \\
Preschool & 2 & 2 & 4 \\
\hline Total & $\mathbf{1 1}$ & $\mathbf{7}$ & $\mathbf{1 8}$ \\
\hline
\end{tabular}

* In rural areas do not exist Theoretical or Vocational High schools.

The leadership persons within the Romanian educational system represent a population of experts in permanent change, most of the positions being obtained by nomination and not by competition. Thus, because it was difficult to ensure a representative sampling, after a seriously analysis together with two academic experts, we decided to use a snowball sampling that allowed the selection of a consistent sample of respondents with experience in educational leadership. The questionnaire was answered voluntarily by 159 persons with leadership positions in the education system: 146 principals 
or assistant principal of educational institutions, 11 school inspectors and two directors of Teacher Training Centres. The respondents come from Bucharest and from 14 countries in Romania, and covering all regions of Romania. $76.7 \%$ of the respondents are female, while $23.3 \%$ are male. $73.6 \%$ of the respondents are qualified as teachers for secondary school or high school, $8.2 \%$ are teachers for primary education, and $18.2 \%$ are preschool teachers. $58.5 \%$ of the respondents have a Master's or a $\mathrm{PhD}$ diploma, and $93.7 \%$ of them have the highest educational degree. Over three quarters $(76.7 \%)$ of the respondents have a seniority of over 20 years in education. Almost a third (29.6\%), respectively almost quarter of them (23.3\%) has a seniority of over ten years, respectively between 5 to 10 years in leadership positions.

\section{Results and discussions}

\subsection{Occupations in the educational field that require $\mathrm{CM}$ tasks}

The International Standard Classification of Occupation 2008 [ISCO-08] (International Labor Office, 2012), is a system of classification and aggregation of occupations at the international level. The occupations in pre-university education that directly refer to tasks in the field of CM are those of Primary and Secondary Education Teachers, Education Methods Specialists in which are included occupations such as Curriculum coordinator, Curriculum developer, Schools inspector or Special Needs Teachers occur. Moreover, the tasks listed in the category of Education Managers, where the school's principals are included, make an indirect reference to CM tasks.

In the Standard Occupational Classification Manual, United States 2018 [SOCM] (Executive Office of the President's Office of Management and Budget 2018), occupations such as Preschool teachers, Postsecondary teachers or occupations as Curriculum and Assessment Director, Curriculum Specialist, Special Educational Curriculum Specialist were included in the category of Instructional Coordinators aim CM competencies. In SOCM, the description of Teacher occupation or of the School Principal occupation does not directly list CM tasks, but on the O*NET Resource Center website (https://www.onetcenter.org/overview.html) developed under the sponsorship of the US Department of Labor/Employment and Training, CM tasks and activities are listed.

The European Qualification framework $[\mathrm{EQF}]$ is "a common reference framework of qualifications, expressed as learning outcomes at increasing levels of proficiency" (European Union [EU], 2018). Based on the eight levels of the EQF (EU, 2018), each European country develops its own classification of occupational standards. We found that, in certain countries, for example Romania (see next paragraphs), CM tasks are required for acceding leadership positions in education and there are no specific occupations in the field of curriculum. In other countries such as UK, specific occupations in the field of CM occur (Office for National Statistics, 2010). For example, occupations such as Teachers, Head teachers and principals, or occupations such as Curriculum adviser, Curriculum development adviser and Curriculum support assistant are included in the category of Education advisers and school inspectors requires CM tasks.

Thus, we identify an international tendency to introduce CM specific occupations in education since the labor market is increasingly requiring specialists in the field of curriculum leadership. The competing positions that are frequently meet on the international labour market (eg see eteach.com, fejobs.com, indeed.com, salary.com) are those of curriculum leader, curriculum director, curriculum manager, curriculum specialist, curriculum designer, curriculum developer, curriculum adviser, instructional coordinator, educational experts.

\subsection{Qualifications in the field of CM within the Romanian educational system}

The EQF defines a qualification as "the formal outcome of an assessment and validation process obtained when a competent body determines that an individual has achieved learning outcomes to the given standards. Qualifications usually take the form of certificates and diplomas awarded following education, training, learning and (sometimes) work" (EU, 2018, 7).

Worldwide, many universities offer study programs in education but only few of them in the CM field. Out of 618 Master' Programs in Education published on masterstudies.com, 106 are in Educational 
Leadership from which in Europe are listed 18 programs in educational management but only one in curriculum. The Romanian Masters Programs are not included on in this database.

In Romania, the National Authority for Qualifications [NAQ] manages the National Register of Qualifications in Higher Education [NRQHE] in which are currently enrolled 16 master's programs as follows: 13 in Educational management, two programs in Educational management and curricular development and one program in CM. There are also teachers training programs of short duration, of maximum 120 hours, which are generally offered by Teacher Training Centres. Some programs cover different topics related to $\mathrm{CM}$ as: Educational management, Leadership and management in school organizations, Project management, Curricular qualification of teachers in primary education for the preparatory class (Teacher Training Centres web site: https://www.edu.ro/casele-corpului-didactic).

\subsection{Occupations that can be practiced by the CM specialists in the Romanian educational system}

For each qualification enrolled in NRQHE, the occupations from the Classification of occupations in Romania [COR] (https://edirect.e-guvernare.ro/informatiigenerale/SitePages/cetateni.aspx?IDC=30) that can be practiced on the labor market are specified. COR represents the system of identification, ranking and coding all occupations carried out in the economy. The occupations of educational manager, curriculum manager or other occupations in the CM field are not included in the COR, therefore qualifications in this field registered in NRQHE aim occupations such as: educational counsellor, educational expert, school inspector, professional competency evaluator and trainer. We found in NRQHE an inconsistency in the fact that for the same qualification, the occupations that can be practiced on the labor market differ according to the program provider. For example, in the case of two master's programs in Educational Management and curricular development, in one of them the occupations belong to the category of specialists in the field of administration, and in the other to the field of specialists in education. In our opinion, the same qualification must offer the possibility of practicing the same occupation, thus a revision of the NRQHE is needed.

The Ministry of National Education and Research created the National body of experts in Educational management [NBEEM] (https://www.edu.ro/cnems) whose members can apply for the positions of principals or assistant principals of educational institutions. At the selection for NBEEM can participate any teacher that proves the accumulation of 60 transferable credits within accredited training programs in the field of educational management (Ministry of Education, Research, Youth and Sport, 2011). Training programs in the field of MC are accepted as a component of educational management. NBEEM (Ministry of National Education, 2017). According to the occupational standard of School Principal (NAQ web site: http://site.anc.edu.ro/), the principals must show MC competences as: coordinates the application of the national curriculum and the school's decision curriculum, monitors the development of extracurricular activities, determines at the school level the way in which the national curriculum is achieved by reference to the official curricular documents. According to the Framework Regulation for the functioning of the pre-university education units (Ministry of National Education and Scientific Research, 2016), in the educational institutions, are setting up different committees as: The Commission for the curriculum, the Commission for evaluation and quality assurance, the Commission for internal managerial control, the Commission of educational programs and projects. The MC qualified teachers can coordinate or can be members of these commissions or of other commissions from the county school inspectorates or of the Ministry of Education.

The master's programs in CM are innovative for the Romanian educational system and answer to the needs of the society, but in terms of employment, the Romanian educational system is still quite rigid. Therefore, even though on the international level the MC qualification related qualifications allow the possibility of occupying specific positions, in Romania the MC qualification is useful for teachers to access different leadership positions in education or for professional development. Thus, appears the need to align the CM qualification in Romania with international trends by introducing specific positions of curriculum manager. 


\subsection{Curriculum manager competences}

In the Romanian educational system, all programs of study (bachelor, masters, training programs, etc.) require the specification of the competences provided by the respective program.

According to the European Parliament Council $(2008,4)$ "competence means the proven ability to use knowledge, skills and personal, social and/or methodological abilities, in work or study situations and in professional and personal development. In the context of the EQF, competence is described in terms of responsibility and autonomy". Ministry of National Education and National Qualifications Authority $(2018,75)$ classify competences in two categories: professional competences and transversal competences that serve to the description of a learning outcome-based qualification.

The opinion of the leadership personnel in education, expressed through questionnaires, regarding the importance of the 12 competences provided it is shown in Figure 1. On a scale with values between 1 to 5, all competencies have obtained an average of over 4 points, which shows the respondents consider all specified competencies to be important for a curriculum manager. The most important competence, which received 5 points from $94.3 \%$ of respondents, is the management of curricular documents. Less important is the competence of research, probably due to the fact that the school principals only apply the curricular reform policies imposed by higher institutions, most often from the Ministry of National Education.

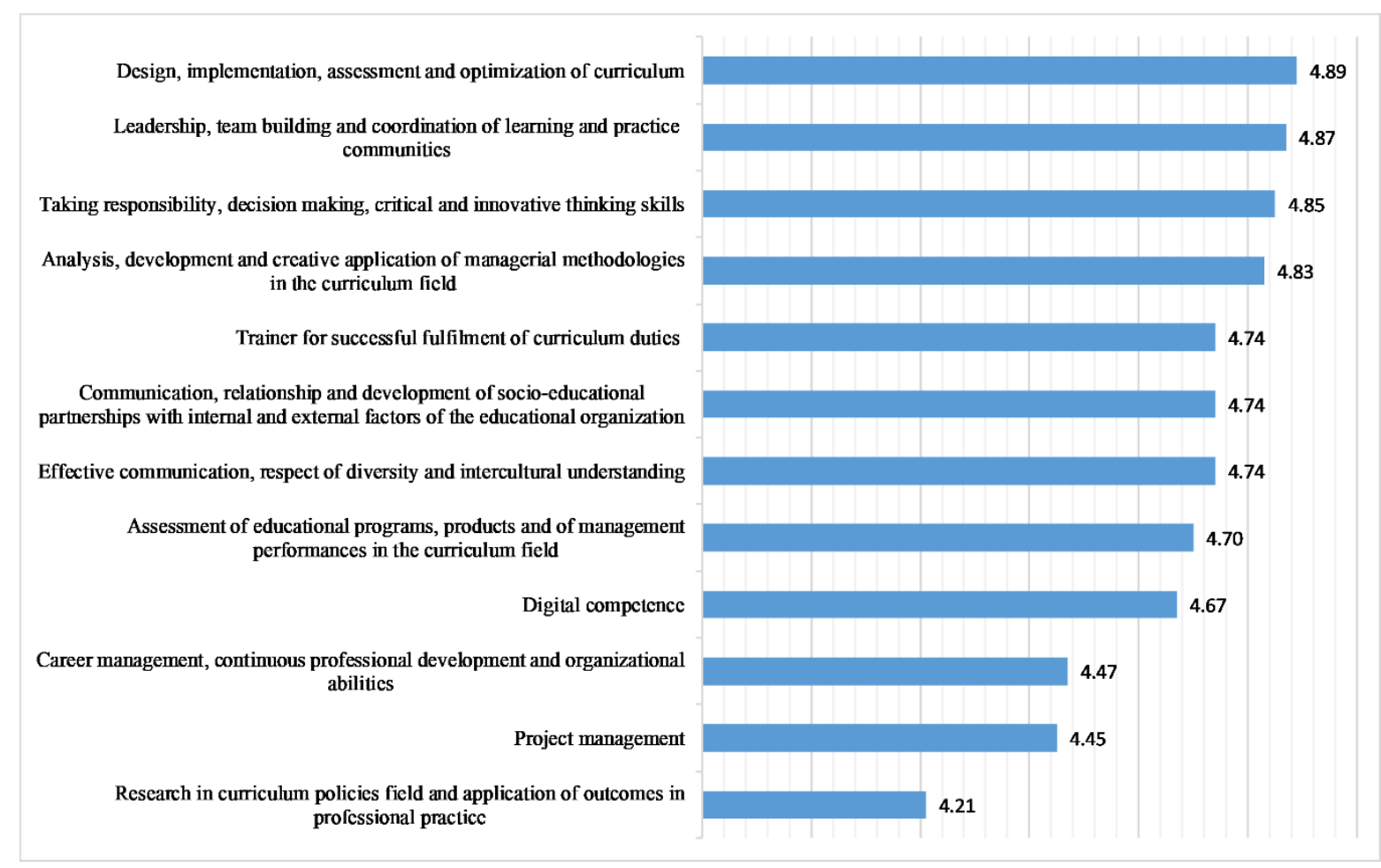

Figure 1 . The hierarchy of the curriculum manager competencies according to their importance

Combined the results from Figure 1 with the discussions in the focus group and individual interviews the curriculum manager competencies were classified into six categories (Table 4).

Table 4. Curriculum manager competencies

Categories of competences

\begin{tabular}{|c|c|c|}
\hline \multirow[t]{2}{*}{$\begin{array}{l}\text { Professional } \\
\text { competences }\end{array}$} & $\begin{array}{l}\text { Research in the } \\
\text { curriculum field }\end{array}$ & $\begin{array}{l}\text { - Research in the field of curriculum policies } \\
\text { - Development of curricular policies } \\
\text { - Developments of curriculum } \\
\text { - Application of the curricular research results in the professional practice }\end{array}$ \\
\hline & Management of & $\begin{array}{l}\text { - Design, implementation, evaluation and optimization of curriculum } \\
\text { - Application / alignment of the local curriculum with the centralized one }\end{array}$ \\
\hline
\end{tabular}




\begin{tabular}{|c|c|}
\hline $\begin{array}{c}\text { the curricular } \\
\text { process }\end{array}$ & $\begin{array}{l}\text { - Analysis, implementation, optimization, revision and evaluation of } \\
\text { curricular documents: educational plan, school curricula, etc. } \\
\text { - Analysis, development and creative application of managerial } \\
\text { methodologies in the curriculum field } \\
\text { - Communication, relationship and development of socio-educational } \\
\text { partnerships with internal and external factors of the educational } \\
\text { organization } \\
\text { - Evaluation of educational programs, products and of managerial } \\
\text { performances in the curriculum field } \\
\text { - Reporting the managerial performances in the curriculum field }\end{array}$ \\
\hline $\begin{array}{l}\text { Management of } \\
\quad \text { instruction }\end{array}$ & $\begin{array}{l}\text { - Coordinates the application of the national curriculum and the school's } \\
\text { decision curriculum } \\
\text { - Activities planning } \\
\text { - Activities management } \\
\text { - Activities monitoring } \\
\text { - Activities adjusting } \\
\text { - Activities evaluation }\end{array}$ \\
\hline $\begin{array}{l}\text { Trainer in the } \\
\text { curriculum field }\end{array}$ & $\begin{array}{l}\text { - Trainer for successful fulfilment of curriculum duties } \\
\text { - Consultant and guide in the field of the curriculum }\end{array}$ \\
\hline $\begin{array}{l}\text { Other } \\
\text { professional } \\
\text { competences }\end{array}$ & $\begin{array}{l}\text { - Basic scientific competences } \\
\text { - The competence of learning how to learn } \\
\text { - Social and civic competences } \\
\text { - Initiative and entrepreneurship } \\
\text { - Cultural awareness and expression }\end{array}$ \\
\hline Transversal competences & $\begin{array}{l}\text { - Effective communication, respect of diversity and intercultural } \\
\text { understanding } \\
\text { - Taking responsibilities, decision making, critical and innovative thinking } \\
\text { skills } \\
\text { - Leadership, teambuilding and coordination of learning and practice } \\
\text { communities } \\
\text { - Organizer } \\
\text { - Project management } \\
\text { - Career management, continuous professional development and } \\
\text { institutional performance } \\
\text { - Digital competence } \\
\text { - Flexibility and availability for changing } \\
\text { - Knowledge of the legislation } \\
\text { - Communication in foreign languages }\end{array}$ \\
\hline
\end{tabular}

\subsection{The necessity of the CM qualification within the Romanian educational system}

Both at the focus group and at the individual interviews, all participants considered the MC qualification necessary within the Romanian educational system. The questionnaire answers gave a 4.67 mean level of necessity on a scale between 1 to 5 , which shows that the respondents consider the $\mathrm{CM}$ qualification being essential.

The respondents note that the frequent curriculum changes require CM competences and that, in each school, there is a need for specialists to implement the official curriculum and to diversify the school's decision curriculum. As a result, based on the analysis of the situation in the Romanian educational system and of the official documents, the respondents consider that the requirement for a school principal to have the status of educational management expert is too wide. They argue that a teacher cannot be an expert in all sub-domains related to educational management, CM being considered as one of the most important sub-domains. From their experience in leadership positions, the respondents consider that a reorganization of the school management would be necessary, so that a curriculum manager being next to the school principal. In addition, each school needs qualified persons in the Curriculum Commission to supervise the adaptation, design, implementation and evaluation of the curriculum taking into account the specific features of the respective school institution. 


\subsection{The current situation and the need of $\mathrm{CM}$ qualified teachers within the Romanian educational system}

The respondents to the questionnaire, from their leadership positions, have an average of 44.4 subordinated persons per institution. In this context, the respondents consider that, on average, 6.9 persons, representing $15.5 \%$ of personnel from their institution are qualified in CM through a master's program in educational management, curricular management or through training programs.

$41.5 \%$ of the respondents consider that there is a high need for CM specialists in their institutions, while $56 \%$ of them consider this an average need. Specifically, the management staff consider that it would take approximately one fifth $(20.3 \%)$, respectively one third (32.9\%) of the teaching staff to be qualified in the CM by 2023 , respectively 2028 . This means that by 2023 over a third $(35.8 \%)$, respectively almost half $(48.4 \%)$ by 2028 , of the teachers must have a qualification in CM. To determine the approximate number of teachers who needs qualification in the CM field, we analysed the School mapping of Romania (Ministry of National Education and Scientific Research, 2018). This includes 18,909 accredited educational institutions (schools and kindergartens). At the regional level, in Cluj county and the neighbouring countries, there are 3,494 educational institutions. Based on these data, over 27,000 teachers nationally, respectively over 5,000 teachers regionally have to be annually qualified in the CM. The existing Master's programs in CM ensure the training of up to 200, respectively 100 graduates at the national and local level, respectively. In addition, the Master's programs in Educational Management provide up to 1000 respectively 100 graduates per year nationally, respectively at regional level. However these Master's programs as well as the training programs form only a part of the competencies required for a curriculum manager. For an adequate training of teachers in the field of $\mathrm{CM}$, it is clear that a significant increase in the number of specific master's programs in this field is needed.

\section{Conclusions and recommendations}

In the last 10-15 years, it is noticed an international tendency of reforming the educational systems that occurs mainly in the field of curriculum and are supported by school principals and teachers who should have CM competences.

Based on this consideration, we conducted a study analysing the CM qualification in education and the competences this qualification requires. We also analyse the current situation and the future needs of CM specialists within the Romanian educational system.

The research consisted of mixing qualitative and quantitative methods as follow: a content analysis of the official documents regarding the qualification of CM (official sites, laws and methodologies); the analysis of the educational programs in the $\mathrm{CM}$ field proposed in Romania; a triangulated methodology comprising: a focus-group, semi-structured interviews and online questionnaires in which 159 persons with leadership positions within the education system answered voluntarily. The three instruments of the triangulated methodology offered us complementary perspectives.

The novelty of this research consists of the identification, centralization and classification of the CM competencies into six categories related to educational practice. In the literature so far, these competences have not been formulated and theoretically grounded, so that for a CM position each employer requests the competencies that he considers necessary without a unitary approach based on a theoretical foundation. The most important competence indicated by over $94 \%$ of the respondents to the questionnaire is the management of the curricular documents. Both at the individual interviews and at the focus group, all participants considered the CM qualification necessary in the Romanian educational system. Four out of five subjects consider that there is a high need for curriculum managers, given that currently only $15.5 \%$ of teachers have such competencies. In the perspective of future years in the educational system in Romania, it would be necessary that over a third of teachers by 2023 , respectively almost half of them by 2028 to be trained and have competence in the field of CM.

Our study is aimed primarily at the decision-makers within the Romanian educational system, who can influence the educational policies for a significant growth of specific programs in the field of CM, for aligning the $\mathrm{CM}$ qualification with international trends by doing legislative changing to introduce 
specific positions of curriculum manager. In addition the study targets the providers of training programs and universities in Romania in order to introduce new CM programs whose curricula to be corelated with competences identified. This study opens a new future research direction for a comprehensive and comparative analysis for other countries regarding $\mathrm{CM}$ occupations.

\section{Bibliography}

Bocoş, M., Chiş, V. (2013). Management curricular. Repere teoretice şi aplicative. [Curriculum Management. Theoretical and applicative benchmarks]. Volume I. Piteşti: Editura Paralela 45.

Boyd, B. (1996). The Principal as Teacher: A Model for Instructional Leadership. NASSP Bulletin, 80 (580): 65-73.

Botha, R. J. (2004). Excellence in leadership: demands on the professional school principal. South African Journal of Education, 24 (3): 239-243. http://www.ajol.info/index.php/saje/article/view/24 $\underline{995 / 20678}(20.08 .2020)$

Bush, T. (2008). Leadership and Management Development in Education. Hawker Brownlow Education.

Bush, T. (2016). School leadership and management in England: the paradox of simultaneous centralisation and decentralization. Research in Educational Administration \& Leadership, 1 (1): 1-23. https://dergipark.org.tr/download/article-file/225363 (20.08.2020)

Classification of Occupations in Romania (COR) web site. https://edirect.eguvernare.ro/informatiigenerale/SitePages/cetateni.aspx?IDC=30 (22.08.2020)

Donmoyer, R., Wagstaff, J. G.. (1990). Principals Can Be Effective Managers and Instructional Leaders. NASSP Bulletin, 74 (525): 20-29.

Eddy-Spicer, D., S. Bubb, P. Earley, James, C. (2019). Headteacher performance management in England: Balancing internal and external accountability through performance leadership. Educational Management Administration \& Leadership 47(2): 170-188.

European Centre for the Development of Vocational Training (Cedefop). (2012). Curriculum reform in Europe. The impact of learning outcomes. Luxemburg: Publications Office of the European Union. https://www.cedefop.europa.eu/files/5529_en.pdf (24.08.2020)

European Commission. (2012). Supporting the Teaching Professions for Better Learning Outcomes. Accompanying the document Communication from the Commission. Rethinking Education: Investing in skills for better socio-economic outcomes. Strasbourg 20.11.2012. https://eurlex.europa.eu/LexUriServ/LexUriServ.do?uri=SWD:2012:0374:FIN:EN:PDF (24.08.2020)

European Commission. (2018). European ideas for better learning: the governance of school education systems. The final report and thematic outputs of the ET2020 Working Group Schools. https://www.schooleducationgateway.eu/downloads/Governance/2018-wgs6-Full-Final-Output.pdf (24.07.2020)

European Parliament Council. (2008). Recommendation of the European parliament and the Council of 23 April 2008. Official Journal of the European Union. https://eurlex.europa.eu/LexUriServ/LexUriServ.do?uri=OJ:C:2008:111:0001:0007:EN:PDF (20.08.2020)

European Trade Union Committee for Education (ETUCE). (2012). School Leadership in Europe: issues challenges and opportunities. Brussels. https://www.cseeetuce.org/images/attachments/SchoolLeadershipsurveyEN.pdf (24.07.2020)

European Union (EU). (2018). The European Qualifications Framework: supporting learning, work and cross-border mobility $10^{\text {th }}$ Anniversary. 
Executive Office of the President Office of Management and Budget. (2018). Standard Occupational Classification Manual, United States 2018. https://www.bls.gov/soc/2018/soc_2018_manual.pdf (24.07.2020)

Flick, U. (2014). An introduction to qualitative research ( $5^{\text {th }}$ ed.). London: Sage ( $1^{\text {st }}$. ed. 1998).

Goslin, K. G. (2009). How instructional leadership is conveyed by high school principals: the findings of three case studies. A paper presented at the International Congress for School Effectiveness and Improvement Canada. 6 January 2009.

International Labour Office. (2012). International Standard Classification of Occupation 2008 (ISCO08). ILO Publications, Geneva. https://www.ilo.org/wcmsp5/groups/public/---dgreports/---dcomm/--publ/documents/publication/wcms_172572.pdf (24.07.2020)

Leaton Gray, S., D. Scott, Mehisto, P. (2018). Curriculum Reform in the European Schools Towards a $21^{\text {st }} \quad$ Century Vision. Cham: Palgrave Macmillan. https://link.springer.com/content/pdf/10.1007\%2F978-3-319-71464-6.pdf (24.07.2020)

Kidd, P. C., Parshall, M. (2000). Getting the focus and the group: enhancing analytical rigor in focus groups research. Qualitative Health Research, 10 (3): 293-308.

Kitchen, H., E. Fordham, K. Henderson, A. Looney, Maghnouj, S. (2017). The Romanian education system, in Romania 2017. OECD Publishing, Paris. https://www.oecd-ilibrary.org/education/romania2017_9789264274051-en (24.07.2020)

Kvale, S. (2008). Doing interviews. London: Sage Publications.

Marsch, C. J. (2004). Key concepts for understanding curriculum. $3^{\text {rd }}$ edition New York: Routledge Falmer.

Mestry, R. (2017). Empowering principals to lead and manage public schools effectively in the 21st century. South African Journal of Education 37 (1): 1-11.

Mestry, R. (2017). Principals' perspectives and experiences of their instructional leadership functions to enhance learner achievement in public schools. Journal of Education, 69: 257- 280.

Ministry of Education, Research, Youth and Sport, Romania. (2011). ORDIN Nr 5549 din 6 octombrie 2011 pentru aprobarea Metodologiei privind organizarea şi desfăş̧urarea concursului de selecţie a cadrelor didactice pentru constituirea corpului naţional de experţi în management educational [Order No. 5549 of 6.10 .2011 on the approval and of the competition for selection of teachers for setting national body of experts in educational management]. https://www.edu.ro/sites/default/files/_fi\%C8\%99iere/Invatamant-

Preuniversitar/2016/management/OM_5549_2011_Metodolgie\%20organizare_desfasurare_concurs_s electie\%20corp\%20experti_CNEME.pdf (24.07.2020)

Ministry of National Education, Romania. (2017). Metodologie privind organizarea și desfăşurarea concursului pentru ocuparea funcțiilor de director și director adjunct din unitățile de invățamânt preuniversitar [Methodology for organizing and conducting the competition for the position of schools' principal and assistant principal]. https://www.edu.ro/sites/default/files/Metodologie\%20Concurs\%20Director\%20si\%20Director\%20A djunct\%20-\%202017\%20\%281\%29.pdf (24.07.2020)

Ministry of National Education and National Qualifications Authority. (2018). Referencing the Romanian Qualifications Framework to the European Qualifications Framework. Project-National Europass centre +EQF NCP 2018-2020, VS/2018/0243. Bucharest. https://ec.europa.eu/ploteus/sites/eac-eqf/files/romanian_referencing_report_21.09.2018_final.pdf (23.07.2020)

Ministry of National Education and Scientific Research. (2016). Regulament cadru de funcționare a unităților de invățământ preuniversitar [Framework regulation for schools functioning]. https://www.edu.ro/sites/default/files/ROFUIP\%20\%20\%20.pdf (24.07.2020) 
Ministry of National Education and Scientific Research. (2018). Cartografia școlară [School maping]. https://www.siiir.edu.ro/carto/ (24.07.2020)

Morphet, E., R. John, Reller, T. (1982). Educational organisation administration. London: PrenticeHall International Inc.

National Authority for Qualifications (NAQ) web site. http://site.anc.edu.ro/; http://site.anc.edu.ro/en/misiune eng/ (24.07.2020)

National Body of Experts in School Management web page. https://www.edu.ro/cnems (22.07.2020)

National Register of Qualifications in Higher Education (NRQHE) web site. http://site.anc.edu.ro/registrul-national-al-calificarilor-din-invatamantul-superior-rncis/ (22.07.2020)

Organization for Economic Co-operation and Development (OECD). (2008). Improving School Leadership Volume 1: Policy and Practice. By Pont B, Nusche D and Moorman H. OECD Publishing, Paris. https://www.oecd.org/education/school/44374889.pdf (24.07.2020)

Office for National Statistics. (2010). Standard Occupational Classification 2010 Volume 2 The coding index. Palgrave Macmillan. https://webarchive.nationalarchives.gov.uk/20160106094533/http://www.ons.gov.uk/ons/guidemethod /classifications/archived-standard-classifications/soc2010---volume-2-of-the-coding--index/index.html (24.07.2020)

O*NET Resource Center web site. https://www.onetcenter.org/overview.html (14.07.2020)

Portin, B. S., Shen, J., Williams, R. C. (1998). The changing principalship and its impact: voices from principals. NASSP Bulletin, 82: 1-8.

Schleicher, A. (ed.). (2012). Preparing teachers to deliver 21-st century skills. in Preparing Teachers and Developing School Leaders for the 21 st Century: lessons from around the World, OECD Publishing, Paris. https://www.oecd-ilibrary.org/docserver/9789264174559-4-en.pdf?expires= $1585121042 \& \mathrm{id}=\mathrm{id} \&$ accname$=$ guest $\&$ checksum $=\mathrm{A} 8191967900732 \mathrm{CC} 4 \mathrm{C} 01 \mathrm{C} 2 \mathrm{E} 583 \mathrm{AF} 1251$ (14.07.2020)

Teacher Training Centres web site. https://www.edu.ro/casele-corpului-didactic (28.07.2020)

Viennet, R., Pont, B. (2017). Education Policy Implementation: A Literature Review and Proposed Framework. OECD Education Working paper No. 162. http://www.oecd.org/officialdocuments/publicdisplaydocumentpdf/?cote=EDU/WKP(2017)11\&docLa nguage $=$ En $(24.07 .2020)$

\section{Authors}

Ioana Magdaș, Babeș-Bolyai University, Cluj-Napoca (Romania). E-mail: ioana.magdas@ubbcluj.ro 
